\title{
TANTANGAN PENANGANAN PERMUKIMAN KUMUH DARI SUDUT PANDANG INSTITUSIONAL: STUDI KASUS KOLEKTIF DI KEL. BINTARO DAN KEL. BANJAR KOTA MATARAM
}

\author{
Saiful Amin ${ }^{1}$ dan Erwin Fahmi ${ }^{2}$ \\ ${ }^{1}$ Program Studi Magister Perencanaan Wilayah dan Kota Universitas Tarumanagara \\ Email:saiful4min@yahoo.com \\ ${ }^{2}$ Program Studi Magister Perencanaan Wilayah dan Kota Universitas Tarumanagara \\ Email: erwin.fahmi@gmail.com
}

Masuk: 17-06-2021, revisi: 06-10-2021, diterima untuk diterbitkan: 27-10-2021

\begin{abstract}
ABSTRAK
Pemukiman kumuh di Indonesia telah ditangani melalui berbagai program sejak sebelum kemerdekaan. Pengalaman program penanganan permukiman kumuh menunjukkan bahwa masih terdapat sejumlah tantangan untuk menyempurnakan program-program dimaksud. Beberapa di antaranya terkait kepastian bermukim dan keberlanjutan program penanganan permukiman kumuh yang holistik. Penelitian ini dilakukan dengan pendekatan penelitian kualitatif dengan menggunakan kerangka kerja The Three Worlds of Action dan metode studi kasus kolektif yang dilakukan di Kel. Bintaro dan Kel. Banjar Kota Mataram. Hasil penelitian menunjukkan bahwa tantangan yang dihadapi pada tingkat pilihan konstitusional dan tingkat pilihan kolektif, yaitu kebijakan yang telah diterapkan di tingkat nasional, belum sepenuhnya konsisten dan koheren dengan keputusan di tingkat pilihan operasional. Hal ini disebabkan karena kebijakan di tingkat konstitusi masih bersifat sektoral, dan belum ada institusi khusus yang menangani permukiman kumuh. Tantangan kedua, pilihan kolektif yang telah disusun pada level pilihan kolektif belum sepenuhnya dioperasionalkan pada level operasional. Hal ini dikarenakan pelibatan masyarakat belum optimal dari perencanaan hingga pelaksanaan dan pilihan kolektif belum sepenuhnya memperhatikan aspek keamanan bertempat tinggal dan keberlanjutan.
\end{abstract}

Kata-kata kunci: program penanganan permukiman kumuh; The Three Worlds of Action; Kelurahan Bintaro dan Kelurahan Banjar Kota Mataram.

\begin{abstract}
Slum settlement in Indonesia has been improved through various programs since before independence. The experiences of slum improvement programs show that there are still a number of challenges to perfecting them. The most critical issues have been, or related to, tenure security and the sustainability of the holistic slum management program. This research was conducted with a qualitative research approach using The Three Worlds of Action framework and a collective case study method conducted in Kel. Bintaro and Kel. Banjar of the City of Mataram. The results showed that the challenges faced at the constitutional choice level and the collective choice level, namely the policies that have been applied at the national level, have not been fully consistent and coherent with decisions at the operational choice level. This is because policies at the constitutional level are still sectoral in nature, and there is no special institution dealing with slum settlements. The second challenge is that the collective choice that has been prepared at the collective choice level has not been fully operationalized at the operational level. This is because community involvement has not been optimal from planning to implementation and the collective choice has not fully paid attention to aspects of security of residence and sustainability.
\end{abstract}

Keywords: slum improvement program; The Three Worlds of Action; Kelurahan Bintaro dan Kelurahan Banjar Kota Mataram.

\section{PENDAHULUAN}

Pada tahun 2060, jumlah penduduk kawasan perkotaan di dunia diperkirakan mencapai 6,5 miliar jiwa. Dari jumlah tersebut, diperkirakan 525 juta orang akan tinggal di permukiman kumuh, dan jumlahnya terus meningkat (UNDP, 2019). Situasi ini berakibat meningkatnya permintaan akan layanan dasar perkotaan, yaitu perumahan dan infrastruktur dasar. Sementara, kemampuan pemerintah untuk menyediakan perumahan publik yang layak terutama untuk kelompok 
berpenghasilan rendah tetap terbatas; demikian juga dengan kapasitas kelembagaan kota untuk memenuhi aspirasi masyarakat perkotaan. Hal tersebut menjadi pemicu terus berkembangnya kantong-kantong permukiman kumuh (Hasnawi, et.al. 2019: 348).

Penanganan permukiman kumuh di Indonesia dalam beberapa dekade terakhir tampaknya belum mampu memberikan penanganan yang berkelanjutan. Upaya penanganan permukiman kumuh dengan cara relokasi pada tahun 1970-an terbukti 'hanya' memindahkan kemiskinan dari satu tempat ke tempat lain (Werlin, 1999). Akar masalah permukiman kumuh terutama terkait tidak tersedianya kebijakan yang menyeluruh yang dapat menjadi acuan penanganan. Akibatnya masing-masing kementerian dan pemerintah daerah menyiapkan skema kegiatan yang berbedabeda (Mungkasa, 2013).

Laporan Raquel Rolnik, Pejabat Khusus PBB untuk Perumahan yang Layak, pada sidang Dewan HAM PBB pada Maret 2014 atas hasil kunjungannya ke lima kota di Indonesia, yaitu Lampung, Jakarta, Surabaya, Makassar dan Kendari, menggambarkan bahwa program pembangunan kita, termasuk program-program penanganan permukiman kumuh, masih belum sepenuhnya menjangkau warga dan kawasan yang paling bawah, termasuk persoalan-persoalan mendasar terkait kepastian bermukim (security of tenure). Hal ini juga terjadi karena beberapa peraturanperundangan terkesan menahan intervensi ke kawasan yang termasuk squatters atau ke warga yang status penghuniannya 'liar', karena kekhawatiran dinilai melanggar hukum (Rujak.org, 2013).

Hasil studi komparatif Sibyan (2020) tentang penanganan permukiman di Gecekondu, Ankara dan di Semanggi, Surakarta memberikan pemahaman yang berbeda terhadap permukiman kumuh dalam perencanaan. Orientasi proyek penataan kawasan kumuh Gecekondu berorientasi pasar. Sebaliknya, orientasi proyek perbaikan kawasan kumuh Semanggi berorientasi publik. Perencanaan dalam kasus Gecekondu memandang penghuni kawasan kumuh sebagai penghuni liar, kelas bawah, kelompok buruh dan pemilih potensial. Sebaliknya, perencanaan dalam kasus Semanggi memandang permukiman kumuh sebagai komunitas yang merupakan bagian dari masyarakat perkotaan.

Berdasarkan pemahaman tersebut, Sibyan (2020) menawarkan perspektif tertentu tentang kawasan kumuh untuk mencapai perencanaan yang sukses. Pertama, permukiman kumuh harus dianggap sebagai komunitas, artinya perencanaan harus mengakomodir komunitas sebagai entitas sosial ekonomi. Kedua, permukiman kumuh harus dilihat sebagai peluang agar perencanaan dapat memanfaatkan modal sosial masyarakat untuk mendorong keberlanjutan dan daya saing perkotaan. Ketiga, kawasan kumuh harus dianggap sebagai bagian dari dinamika perkotaan tempat transformasi sosial, ekonomi dan spasial terjadi dan berkontribusi pada pembangunan perkotaan. Melalui perspektif tersebut, penataan kawasan kumuh tidak hanya tentang formalisasi ruang, perbaikan fisik atau peningkatan ekonomi, melainkan juga harus tentang pemberdayaan masyarakat dan transformasi sosial yang berkontribusi terhadap pembangunan perkotaan. (Sibyan et.al, 2020: 9-10).

Pendekatan perbaikan kawasan kumuh telah berevolusi seiring waktu. Beberapa studi telah menunjukkan bahwa pendekatan bervariasi dalam ruang lingkup dan fokus. Strategi sebelumnya, termasuk pengabaian, penggusuran, pemberantasan, pembongkaran dan pemukiman kembali, pada akhirnya gagal secara efektif dalam mengatasi masalah kumuh (Usavagovitwong, 2012; Mbati, 2011). Turner (1968), menganjurkan untuk selanjutnya melakukan perbaikan permukiman dengan peran negara yang terbatas. Pendekatan-pendekatan selanjutnya memberi lebih banyak pengakuan terhadap permukiman (Fernandes, 2002). Tujuan utamanya adalah untuk meningkatkan permukiman informal yang ada melalui berbagai intervensi atau pendekatan yang 
meliputi: penyediaan jaminan kepemilikan (security of tenure), infrastruktur, perbaikan perumahan, dukungan sosial, pelatihan, kredit mikro, penguatan institusi dan perubahan dalam kerangka peraturan dan langkah-langkah densifikasi (Huchzermeyer, 2008; UN-Habitat, 2003 dalam Mangira et al, 2020: 2026 ).

Temuan-temuan di atas menunjukkan bahwa program penanganan permukiman terutama permukiman kumuh di Indonesia masih memiliki tantangan terkait keberlanjutan program dan kepastian bermukim. Dua hal ini sangat berpengaruh pada keberhasilan program penanganan permukiman kumuh. Namun demikian, hasil penelitian yang disimpulkan oleh United Nations Development Group (UNDG) pada tahun 2010 menunjukkan bahwa pola suksesi penanganan permukiman kumuh telah mendekati pola yang holistik. Penanganan permukiman kumuh yang holistik setidaknya mencakup empat aspek penting, yaitu: (1) peningkatan produktivitas masyarakat miskin perkotaan dengan mengembangkan keterampilan dan menyediakan akses ke kredit mikro, (2) peningkatan kondisi kehidupan masyarakat miskin melalui penyediaan layanan dasar dan pengembangan permukiman kumuh secara in situ, (3) pemberian jaminan kepemilikan kepada keluarga miskin yang tinggal di permukiman yang tidak sah dan meningkatkan akses mereka ke perumahan murah dan pembiayaan perumahan bersubsidi, (4) pemberdayaan masyarakat miskin perkotaan melalui pengembangan masyarakat dan mendorong partisipasi mereka dalam pengambilan keputusan (Bah 2018: 226).

Kota Mataram merupakan salah satu kota di Indonesia yang melaksanakan program-program penanggulangan kemiskinan maupun penanganan permukiman kumuh. Sejak tahun 1999 sejumlah program pemerintah telah dijalankan, mulai Program Penanggulangan Kemiskinan di Perkotaan (P2KP) sampai dengan Program Kota Tanpa Kumuh (KOTAKU). Pada tahun 2013 Kota Mataram menetapkan kawasan permukiman kumuhnya sebesar 303,58 Ha sesuai dengan SK Walikota Mataram No. 463/IV/2013 tentang Penetapan Lokasi Perumahan Kumuh dan Permukiman Kumuh. Kawasan-kawasan permukiman kumuh tersebut tersebar di 25 kelurahan dan 6 kecamatan. Kawasan permukiman kumuh di Kota Mataram dibagi menjadi 4 (empat) klaster kawasan, yaitu: Kawasan Pesisir, Kawasan DAS Jangkok, Kawasan DAS Ancar dan Kawasan Perdagangan dan Bisnis. Berdasarkan Memorandum Program Rencana Pencegahan dan Peningkatan Kualitas Permukiman Kumuh Perkotaan (RP2KPKP) Kota Mataram Tahun 20152019, Kawasan Pesisir merupakan prioritas pertama penanganan.

Tabel 1. Profil Kelurahan Bintaro dan Kelurahan Banjar, Kota Mataram

\begin{tabular}{llcc}
\hline No & \multicolumn{1}{c}{ Aspek } & Kelurahan Bintaro & Kelurahan Banjar \\
\hline 1. & Luas (Ha) & 16,04 & 13,24 \\
\hline 2. & Tipologi & Permukiman kumuh tepi pantai & Permukiman kumuh tepi sungai \\
\hline 3. & Kategori & Tingkat kekumuhan ringan & Tingkat kekumuhan ringan \\
\hline 4. & Jumlah RT & 14 & 17 \\
\hline 5. & Demografi: & 3.674 & 3.704 \\
a & Jumlah Penduduk (jiwa) & 1000 & 976 \\
\hline b & Kepala Keluarga (KK) & 687 & 501 \\
\hline c & Jumlah KK yang termasuk MBR & $\begin{array}{c}\text { Sektor jasa dan perdagangan } \\
(58,4 \%), \text { Nelayan, pegawai } \\
\text { negeri, konstruksi (34\%) }\end{array}$ & $\begin{array}{c}\text { Sektor jasa dan perdagangan } \\
(77,9 \%), \text { konstruksi, pegawai } \\
\text { negeri, dan lain-lain (11\%) }\end{array}$ \\
\hline 6. & Mata Pencaharian & &
\end{tabular}

Sumber: pendataan lapangan, 2015

\footnotetext{
${ }^{1}$ Kekumuhan ringan artinya permukiman yang memiliki skor permasalahan kekumuhan berkisar antara 19-44 dari interval skor 0-95. Skor <19 termasuk tidak kumuh; sementara skor 45-70 termasuk kekumuhan sedang dan skor 71-95 termasuk kekumuhan berat. Perhitungan skor dilakukan berdasarkan Permen PUPR No 2/2016 tentang Peningkatan Kualitas terhadap Perumahan Kumuh dan Permukiman Kumuh
} 
Teori institusional luas digunakan untuk mengkaji persoalan kebijakan publik, termasuk di bidang perkotaan (Kiser and Ostrom,1982; Ostrom, Tiebout and Warren, 1961). E. Ostrom (1992) mendefinisikan institusi sebagai "...the set of rules actually used (the working rules or rules-inuse) by a set of individuals to organize repetitive activities that produce outcomes affecting those individuals and potentially affecting others". Kajian penanganan permukiman kumuh termasuk dalam pengertian institusi menurut E.Ostrom di atas, karena institusi penanganan permukiman kumuh adalah "seperangkat kebijakan penanganan permukiman kumuh; aturan kerja digunakan untuk menentukan siapa yang memenuhi syarat untuk membuat keputusan di berbagai tingkatan; tindakan apa yang boleh, harus atau terlarang dilakukan; prosedur apa yang harus diikuti, informasi apa yang perlu disediakan, dan biaya dan imbalan apa yang diterima individu maupun kolektif" sebagai hasil dari tindakan mereka". (E. Ostrom dalam Cole Daniel H, 2013: 109)

Pada penelitian ini, penanganan permukiman kumuh dianggap sebagai institutional governance yang dapat dikaji melalui pendekatan institusional "Three Worlds of Action". Model pendekatan ini berupaya untuk mengkaji konsistensi dan koherensi keputusan atau kebijakan pada 3 (tiga) tingkat pengambilan keputusan, yakni tingkat pilihan operasional, tingkat pilihan kolektif dan tingkat pilihan konstitusional. Pada tingkat pilihan operasional, kajian dilakukan dengan cara mengidentifikasi pola penanganan permukiman kumuh di tingkat komunitas. Pada tingkat pilihan kolektif dilakukan identifikasi kebijakan Pemerintah Daerah terkait strategi penanganan permukiman kumuh. Sedangkan pada tingkat pilhan konstitusional dilakukan identifikasi kebijakan mendasar dalam penanganan permukiman kumuh. Kebijakan atau keputusan pada tiga pilihan pengambilan keputusan tersebut seyogianya konsisten dan koheren satu sama lain. Namun, dalam konteks ini, Fahmi, et.al (2003: 7) menegaskan bahwa kebijakan atau keputusan pada tingkat pilihan konstitusional dapat mendukung (atau menghambat) tingkat pilihan operasional atau kolektif. Namun kebijakan atau keputusan di tingkat pilihan konstitusional juga dapat dikoreksi dengan akumulasi pengalaman dan pelajaran berharga (praktik terbaik) di tingkat pilihan kolektif dan tingkat pilihan operasional.

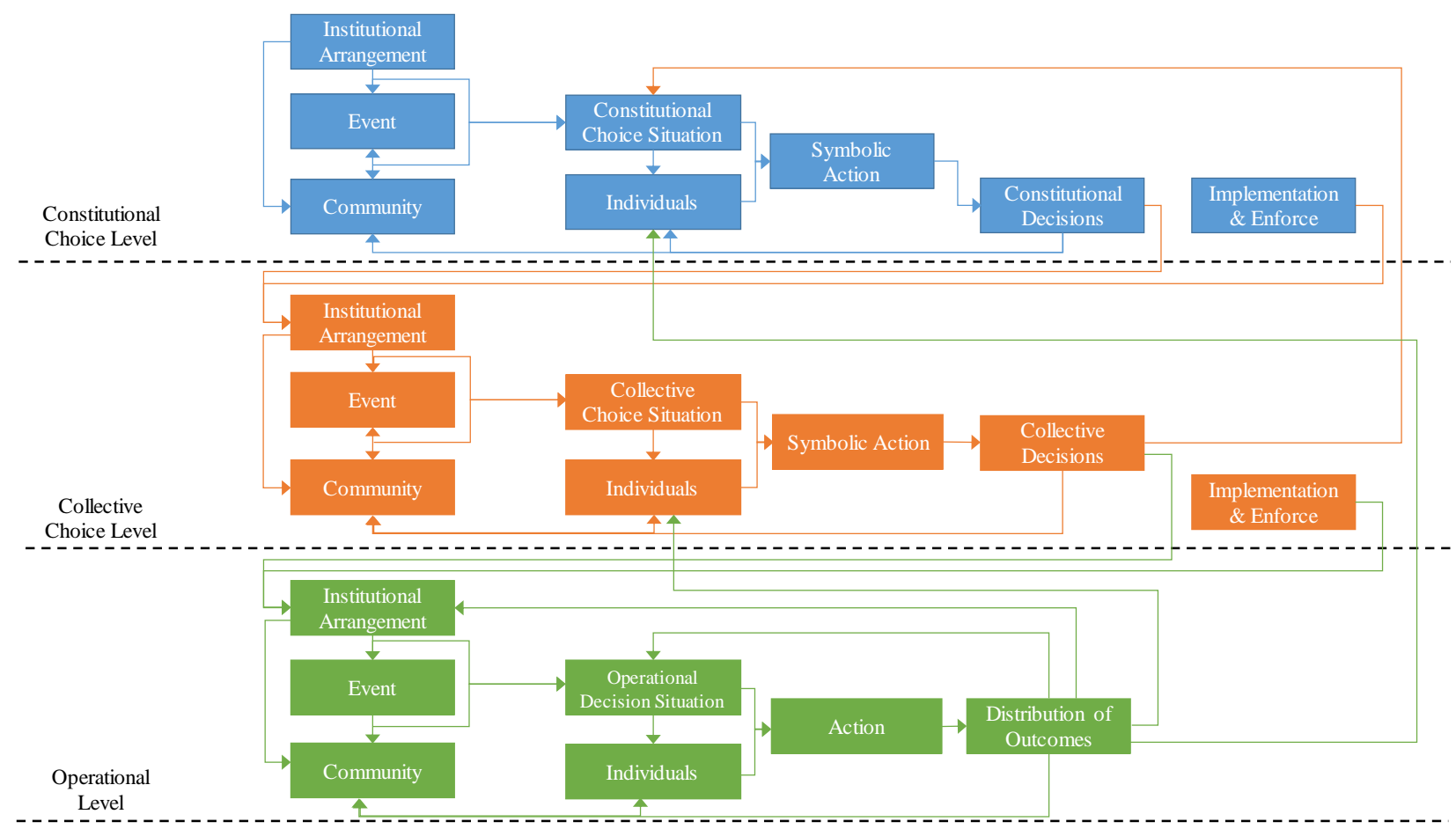

Gambar 1. The Three Worlds of Action

Sumber: Kacaribu 2019: 48 


\section{METODE PENELITIAN}

Pendekatan penelitian yang digunakan adalah pendekatan penelitian kualitatif, dengan studi kasus kolektif di Kelurahan Bintaro dan Kelurahan Banjar, Kota Mataram. Menurut Fahmi (2020: 31), studi kasus kolektif adalah instrumental case study yang dilaksanakan pada lebih dari 1 kasus. Metode studi kasus kolektif dipilih karena kedua kasus dipandang dapat merefleksikan satu konstruksi teoritis tertentu, yakni berkaitan dengan tantangan penanganan permukiman kumuh di Indonesia. Lebih lanjut, penelitian ini juga menggunakan kerangka teoritis The Three Worlds of Action, sebagaimana dirumuskan oleh Kiser dan Ostrom (1982) di atas.

Penerapan teori ini dinilai sangat relevan, karena pendekatan ini berupaya untuk mengidentifikasi konsistensi dan koherensi tindakan di 3 (tiga) tingkat pengambilan keputusan, yaitu tingkat pilihan operasional, tingkat pilihan kolektif dan tingkat pilihan konstitusional. Penerapan kerangka tersebut pada penelitian ini adalah :

Tabel 2. Penerapan kerangka The Three Worlds of Action Pada Penelitian

\begin{tabular}{|c|c|}
\hline Tingkatan & Kajian \\
\hline $\begin{array}{ll}\text { Tingkat pilihan } \\
\text { konstitusional }\end{array}$ & $\begin{array}{l}\text { mengidentifikasi peraturan-perundangan tingkat nasional yang mengatur atau } \\
\text { berpengaruh dalam pelaksanaan penanganan permukiman kumuh. } \\
\text { Contoh: mengkaji koherensi Peraturan Pemerintah No. 38/2011 tentang Sungai pasal } \\
3 \text { (1) (bahwa "sungai dikuasai oleh negara dan merupakan kekayaan negara") dengan } \\
\text { PP } 24 \text { Tahun } 1997 \text { pasal } 24 \text { tentang Pendaftaran Tanah (bahwa "warga yang sudah } \\
\text { menghuni suatu bidang tanah selama } 20 \text { tahun atau lebih secara berturut-turut dan } \\
\text { dengan itikad baik, dapat memiliki hak untuk mengajukan kepemilikan tanah"). } \\
\text { Kajian yang dilakukan adalah: } \\
\text { - Apakah kedua kebijakan tersebut saling koheren/konsisten atau tidak? } \\
\text { - Bagaimana pengaruh kebijakan tersebut di tingkat pilihan kolektif dan/atai } \\
\text { operasional? }\end{array}$ \\
\hline Tingka & $\begin{array}{l}\text { mengidentifikasi kebijakan Pemerintah Daerah (provinsi dan kota) dalampenanganan } \\
\text { kumuh } \\
\text { Contoh: Pemda Kota Mataram menetapkan garis sempadan pantai dan sungai dan } \\
\text { merencanakan relokasi atau ganti rugi lahan warga yang terkena garissempadan. } \\
\text { Kajian yang dilakukan adalah: } \\
\text { - Bagaimana tafsiran Pemda terkait peraturan-perundangan yang mengatur hal } \\
\quad \text { tersebut? Bagaimana pula penerapannya di lapangan (tingkat operasional)? }\end{array}$ \\
\hline $\begin{array}{l}\text { Tingkat } \\
\text { operasional }\end{array}$ & $\begin{array}{l}\text { mengidentifikasi pola pelaksanaan penanganan permukiman kumuh di dua kelurahan } \\
\text { Contoh: warga yang direlokasi tidak sepenuhnya menempati lahan yang telah } \\
\text { disediakan. } \\
\text { Kajian yang dilakukan adalah: } \\
\text { - Bagaimana informasi, dan partisipasi masyarakat dilibatkan pada proses } \\
\text { relokasi? Mengapa sebagian masyarakat tidak menempati lahan yang telah } \\
\text { disediakan, dan malah kembali ke tempat semula? }\end{array}$ \\
\hline
\end{tabular}

Sumber: Olahan peneliti

Pengumpulan data dalam penelitian ini dilakukan melalui studi literatur/dokumentasi, data statistik wilayah penelitian, peta, dan lain-lain. Pengumpulan data primer dilakukan melalui wawancara dengan dinas terkait, pelaku pemberdayaan maupun masyarakat di Kelurahan Bintaro dan Kelurahan Banjar. Selain itu, juga dilakukan observasi lapangan, dan pemeriksaaan artefak program penanganan permukiman kumuh sebelumnya.

\section{HASIL DAN PEMBAHASAN}

\section{Evaluasi Perkembangan Program Penanganan Permukiman Kumuh Yang Telah Berlangsung di Indonesia.}

Evaluasi terhadap pelaksanaan program-program penanganan permukiman kumuh yang telah berlangsung sejak tahun 1969, terutama program yang bersifat masif, adalah sebagai berikut: 
Tabel 3. Evaluasi Pelaksanaan Program Penanganan Permukiman Kumuh

Di Indonesia, 1969 - 2018

\begin{tabular}{|c|c|c|c|c|}
\hline No & Program & $\begin{array}{c}\text { Fokus Pelaksanaan } \\
\text { Program }\end{array}$ & Pelaku & Dampak \\
\hline 1 & $\begin{array}{l}\text { Kampong } \\
\text { Improvemen } \\
\text { t Program } \\
\text { (KIP) }\end{array}$ & 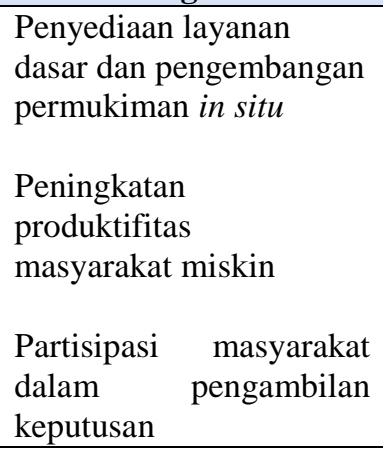 & $\begin{array}{l}\text { - Pemerintah } \\
\text { Pusat } \\
\text { - Pemerintah } \\
\text { Kota/Kab } \\
\text { - } / \text { LSM } \\
\text { - Perguruan } \\
\text { Tinggi } \\
\text { - Kelompok } \\
\text { Masyarakat }\end{array}$ & $\begin{array}{l}\text { Program ini mampu meningkatkan kualitas } \\
\text { lingkungan permukiman menjadi layak huni; } \\
\text { peningkatan ekonomi masyarakat lokal dengan } \\
\text { kesadaran dan partisipasi aktif dari masyarakat } \\
\text { setempat. Namun untuk keberlanjutan jangka } \\
\text { panjang, akibat lemahnya jaminan kepastian } \\
\text { bermukim dan lemahnya akses terhadap } \\
\text { perumahan murah, permukiman tersebut kembali } \\
\text { kumuh dan bahkan tergusur. }\end{array}$ \\
\hline 2 & $\begin{array}{l}\text { Program } \\
\text { Penanggula } \\
\text { ngan } \\
\text { Kemiskinan } \\
\text { di Perkotaan } \\
\text { (P2KP) }\end{array}$ & $\begin{array}{l}\text { Peningkatan produktifitas } \\
\text { masyarakat miskin; } \\
\text { Partisipasi masyarakat } \\
\text { dalam pengambilan } \\
\text { keputusan }\end{array}$ & $\begin{array}{l}\text { - Pemerintah } \\
\text { Pusat } \\
\text { - Pemerintah } \\
\text { Prov } \\
\text { - Pemerintah } \\
\text { Kota/Kab } \\
\text { - Pemerintah } \\
\text { Kecamatan } \\
\text { - LSM } \\
\text { - Kelompok } \\
\text { Masyarakat }\end{array}$ & $\begin{array}{l}\text { Program ini dinilai kuat dalam pemberdayaan } \\
\text { kemandirian masyarakat. Program menumbuhkan } \\
\text { kesadaran masyarakat dalam merencanakan dan } \\
\text { mengakses pendanaan dari berbagai sumber untuk } \\
\text { peningkatan ekonomi lokal dan infrastruktur } \\
\text { permukiman. Pinjaman dana bergulir dari program } \\
\text { ini dinilai telah berkontribusi mengurangi angka } \\
\text { kemiskinan. Perbaikan infrastruktur permukiman } \\
\text { tidak merata di semua lokasi karena tergantung } \\
\text { dari "political will" pemda setempat. Namun } \\
\text { demikian, lemahnya jaminan kepastian bermukim } \\
\text { dan akses permumahan murah mengakibatkan } \\
\text { komunitas dampingan rentan mengalami } \\
\text { permasalahan keberlanjutan jangka panjang, } \\
\text { seperti pada Program KIP }\end{array}$ \\
\hline
\end{tabular}

- Pemerintah Pusat

Jaminan kepastian bermukim

Neighborho Penyediaan layanan

od

Upgrading

3 and Shelter

Sector

Project

(NUSSP)
- Pemerintah $\mathrm{Kota} / \mathrm{Kab}$

- Pihak Swasta

- Kelompok Masyarakat dasar dan pengembangan

permukiman in situ

Akses ke perumahan

murah

Partisipasi masyarakat dalam pengambilan keputusan
Program ini telah mampu memberikan jaminan kepastian bermukim dengan memfasilitasi sertifikasi tanah, fasilitasi ke akses perumahan murah dengan cara kredit dan pemberian bantuan PSU (prasarana dan sarana umum) pada permukiman kumuh. Program ini memfasilitasi partisipasi masyarakat dalam kelembagaan swadaya yang mampu merencanakan dan mengelola hasil pembangunan. Namun pelaksanaan kegiatan lebih banyak dilakukan oleh pihak ketiga. Program ini mendorong kemandirian pemda dan masyarakat dalam rangka mengakses kredit perumahan murah dengan pihak pengembang.

\begin{tabular}{|c|c|c|c|c|}
\hline 4 & $\begin{array}{l}\text { Program } \\
\text { Nasional } \\
\text { Pemberdaya } \\
\text { an } \\
\text { Masyarakat } \\
\text { (PNPM) } \\
\text { Mandiri } \\
\text { Perkotaan }\end{array}$ & $\begin{array}{l}\text { Penyediaan layanan } \\
\text { dasar dan pengembangan } \\
\text { permukiman in situ } \\
\text { Peningkatan } \\
\text { produktifitas masyarakat } \\
\text { miskin } \\
\begin{array}{l}\text { Partisipasi masyarakat } \\
\text { dalam pengambilan }\end{array}\end{array}$ & $\begin{array}{l}\text { - Pemerintah } \\
\text { Pusat } \\
\text { - Pemerintah } \\
\text { Prov } \\
\text { - Pemerintah } \\
\text { Kota/Kab } \\
\text { - Pemerintah } \\
\text { Kecamatan } \\
\text { - NGO/LSM }\end{array}$ & $\begin{array}{l}\text { Program ini mewarisi dan melanjutkan } \\
\text { kelembagaan yang telah dibentuk oleh Program } \\
\text { P2KP dengan menambahkan stimulan dana } \\
\text { bantuan infrastruktur permukiman setiap tahun. } \\
\text { Selain penurunan angka kemiskinan, program ini } \\
\text { juga berkontribusi dalam peningkatan rumah layak } \\
\text { huni dan perbaikan infrastruktur permukiman. } \\
\text { Namun kawasan permukiman squatters tidak } \\
\text { sepenuhnya tersentuh karena lemahnya intervensi } \\
\text { jaminan kepastian bermukim dan juga lemahnya }\end{array}$ \\
\hline
\end{tabular}




\begin{tabular}{|c|c|c|c|c|}
\hline No & Program & $\begin{array}{c}\text { Fokus Pelaksanaan } \\
\text { Program }\end{array}$ & Pelaku & Dampak \\
\hline & & keputusan & $\begin{array}{ll}\text { - } & \text { Kelompok } \\
& \text { Masyarakat }\end{array}$ & $\begin{array}{l}\text { fasilitasi akses terhadap perumahan murah. } \\
\text { Kawasan squatters tersebut dikhawatirkan } \\
\text { menjadi terpinggirkan, kembali kumuh dan bahkan } \\
\text { tergusur }\end{array}$ \\
\hline 5 & $\begin{array}{l}\text { Program } \\
\text { Kota Tanpa } \\
\text { Kumuh } \\
\text { (KOTAKU) }\end{array}$ & $\begin{array}{l}\text { Penyediaan layanan } \\
\text { dasar dan pengembangan } \\
\text { permukiman in situ } \\
\text { Peningkatan } \\
\text { produktifitas masyarakat } \\
\text { miskin } \\
\text { Partisipasi masyarakat } \\
\text { dalam pengambilan } \\
\text { keputusan }\end{array}$ & $\begin{array}{ll}\text { - } & \text { Pemerintah } \\
& \text { Pusat } \\
\text { - } & \text { Pemerintah } \\
& \text { Prov } \\
\text { - } & \text { Pemerintah } \\
& \text { Kota/Kab } \\
\text { - } & \text { NGO/LSM } \\
\text { - Kelompok } \\
\text { Masyarakat }\end{array}$ & $\begin{array}{l}\text { Program ini melanjutkan kelembagaan masyarakat } \\
\text { yang telah terbentuk di P2KP/PNPM Mandiri } \\
\text { Perkotaan. Dampak program terutama pada } \\
\text { penanganan infrastruktur permukiman kumuh. } \\
\text { Kepastian bermukim pada permukiman squatters } \\
\text { mulai diintervensi dengan permukiman kembali } \\
\text { walaupun belum sepenuhnya digarap, lebih } \\
\text { banyak dilakukan pada pemda yang memiliki } \\
\text { komitmen pada pemenuhan kepastian bermukim. } \\
\text { Akses terhadap perumahan murah tidak difasilitasi } \\
\text { dalam program ini sehingga masih menimbulkan } \\
\text { kekhawatiran terkait keberlanjutan jangka panjang } \\
\text { agar tidak kembali menjadi permukiman kumuh. } \\
\text { Peningkatan ekonomi difasilitasi melalui } \\
\text { perencanaan masyarakat dan dorongan pemasaran } \\
\text { kepada berbagai pihak. }\end{array}$ \\
\hline
\end{tabular}

Sumber: Olahan peneliti

Dengan melihat fokus pelaksanaan, pihak-pihak yang terlibat, dan dampak program di atas, maka ke depan arah-arah penanganan permukiman kumuh yang seyogianya ditempuh adalah dengan memberikan jaminan kepastian bermukim di awal berupa kepastian hak atas tanah, seperti: hak milik, kepemilikan komunal, hak sewa, hak guna bangunan, hak pakai, atau lainnya. Dengan memberikan jaminan kepastian bermukim di awal, dapat melepas mereka dari status penguasaan "illegal", yang menimbulkan rasa was-was terhadap potensi penggusuran dan tindakan tidak nyaman lainnya.

Kebijakan/Perundangan dan Program Penanganan Permukiman Kumuh di Tingkat Pusat Evaluasi kebijakan yang dikeluarkan pada tingkat konsitusional menunjukkan bahwa belum sepenuhnya kebijakan-kebijakan tersebut mengakomodir semua aspek penanganan permukiman yang holistik. Selain itu juga, masih terdapat ketidakkoherenan dan/atau ketidakkonsistenan antara satu kebijakan dan kebijakan lainnya. Hal ini menyebabkan kesulitan di tingkat pemerintah daerah (tingkat kolektif) untuk mengimplementasikan dan/atau mensinkronkan kebijakan-kebijakan tersebut dengan keputusan-keputusan di tingkat pilihan kolektif (collective choice). Beberapa kebijakan yang masih tidak koheren dan/atau tidak konsisten dapat dilihat pada tabel berikut : 
Tabel 4. Analisis Kebijakan/Perundangan terhadap Aspek Penanganan Permukiman Kumuh yang Holistik

\begin{tabular}{|c|c|c|c|c|c|}
\hline $\begin{array}{l}\text { Level } \\
\text { Kebijakan/ } \\
\text { Perundang- } \\
\text { undangan }\end{array}$ & $\begin{array}{l}\text { Jaminan } \\
\text { kepastian } \\
\text { bermukim }\end{array}$ & $\begin{array}{l}\text { Penyediaan } \\
\text { layanan dasar dan } \\
\text { pengembangan } \\
\text { permukiman in situ }\end{array}$ & $\begin{array}{l}\text { Peningkatan } \\
\text { produktifitas } \\
\text { masyarakat } \\
\text { miskin }\end{array}$ & $\begin{array}{c}\text { Akses ke } \\
\text { perumahan murah }\end{array}$ & $\begin{array}{l}\text { Partisipasi masyarakat dalam } \\
\text { pengambilan keputusan }\end{array}$ \\
\hline Perundangan & $\begin{array}{l}\text { UU No } 1 \text { Tahun } \\
2011 \text { tentang } \\
\text { Perumahan dan } \\
\text { Kawasan } \\
\text { Permukiman, } \\
\text { pada } \\
\text { penjelasan } \\
\text { pasal 94 ayat } \\
\text { (2) tentang } \\
\text { prinsip } \\
\text { kepastian } \\
\text { bermukim } \\
\text { menjelaskan } \\
\text { bahwa hal } \\
\text { tersebut } \\
\text { dilaksanakan } \\
\text { dengan cara } \\
\text { menghindari } \\
\text { penggusuran } \\
\text { paksa yang } \\
\text { tidak } \\
\text { manusiawi, } \\
\text { serta } \\
\text { mengutamakan } \\
\text { cara } \\
\text { memandang } \\
\text { tempat tinggal } \\
\text { sebagai hak } \\
\text { dasar. Tidak } \\
\text { konsisten } \\
\text { dengan } \\
\text { 26/2007 } \\
\text { tentang } \\
\text { Penataan } \\
\text { Ruang pasal } \\
\text { 61-63 dan UU } \\
\text { 51/prp/196o } \\
\text { tentang } \\
\text { Larangan } \\
\text { Pemakaian }\end{array}$ & 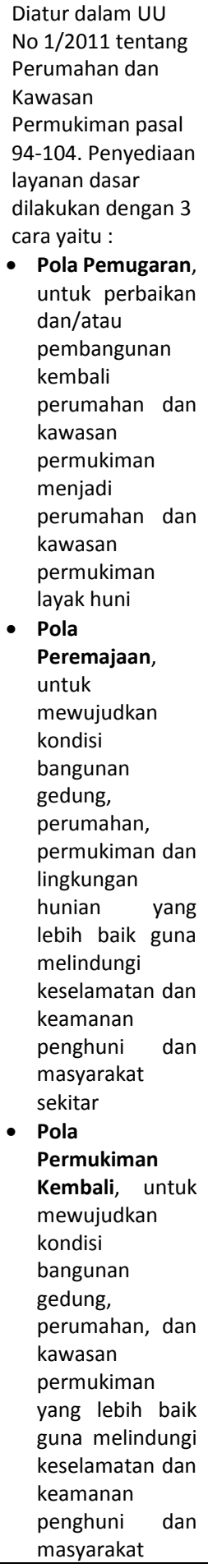 & 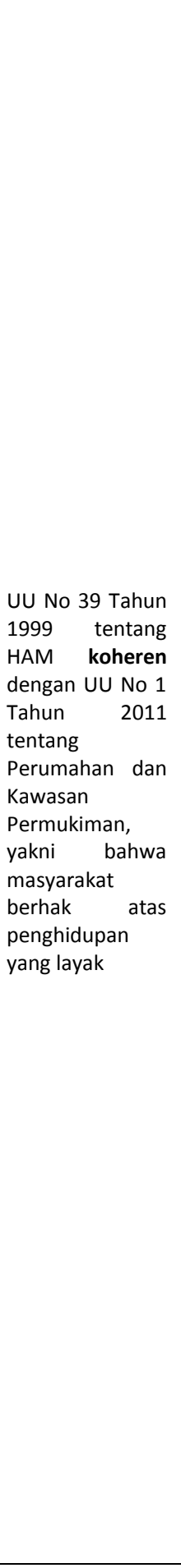 & $\begin{array}{l}\text { Diatur UU No } 1 \\
\text { Tahun } 2011 \\
\text { tentang } \\
\text { Perumahan dan } \\
\text { Kawasan } \\
\text { Permukiman pasal } \\
\text { 13-20, pasal 54-55 } \\
\text { dan pasal } 126 . \\
\text { - Pemerintah } \\
\text { Pusat, Propinsi } \\
\text { dan } \\
\text { Kota/Kabupaten } \\
\text { wajib } \\
\text { memfasilitasi } \\
\text { perumahan bagi } \\
\text { masyarakat } \\
\text { berpenghasilan } \\
\text { rendah (MBR) } \\
\text { - Kemudahan } \\
\text { pembangunan } \\
\text { dan perolehan } \\
\text { rumah bagi } \\
\text { MBR. } \\
\text { pembiayaan } \\
\text { primer } \\
\text { perumahan } \\
\text { dilakukan oleh } \\
\text { Badan Hukum. }\end{array}$ & $\begin{array}{l}\text { Diatur dalam UU No 1/2011 } \\
\text { tentang Perumahan dan } \\
\text { Kawasan Permukiman pasal } \\
131 \\
\text { - Pelibatan masyarakat diatur } \\
\text { sejak perencanaan, } \\
\text { pelaksanaan, pemanfaatan } \\
\text { dan pemeliharaan } \\
\text { - Pelibatan masyarakat } \\
\text { dilakukan melalui forum PKP }\end{array}$ \\
\hline
\end{tabular}




\begin{tabular}{|c|c|c|c|c|c|}
\hline $\begin{array}{l}\text { Level } \\
\text { Kebijakan/ } \\
\text { Perundang- } \\
\text { undangan }\end{array}$ & $\begin{array}{l}\text { Jaminan } \\
\text { kepastian } \\
\text { bermukim }\end{array}$ & $\begin{array}{c}\text { Penyediaan } \\
\text { layanan dasar dan } \\
\text { pengembangan } \\
\text { permukiman in situ }\end{array}$ & $\begin{array}{l}\text { Peningkatan } \\
\text { produktifitas } \\
\text { masyarakat } \\
\text { miskin }\end{array}$ & $\begin{array}{c}\text { Akses ke } \\
\text { perumahan murah }\end{array}$ & $\begin{array}{l}\text { Partisipasi masyarakat dalam } \\
\text { pengambilan keputusan }\end{array}$ \\
\hline $\begin{array}{l}\text { Peraturan } \\
\text { Pemerintah }\end{array}$ & $\begin{array}{l}\text { PP } 24 \text { Tahun } \\
1997 \text { tentang } \\
\text { Pendaftaran } \\
\text { Tanah pasal } 24 \\
\text { tidak konsisten } \\
\text { dengan PP No. } \\
38 / 2011 \\
\text { tentang Sungai } \\
\text { pasal } 3\end{array}$ & 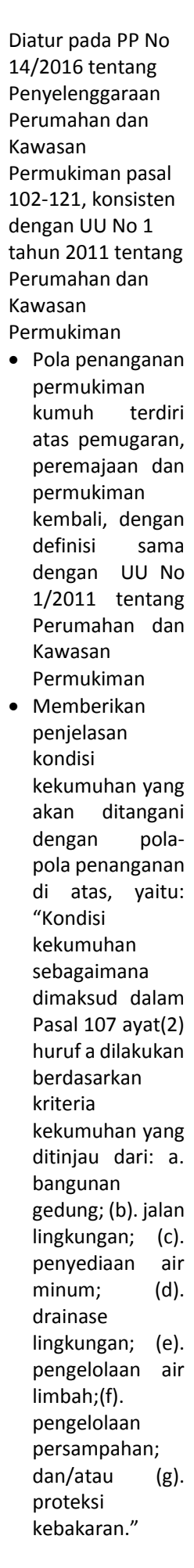 & 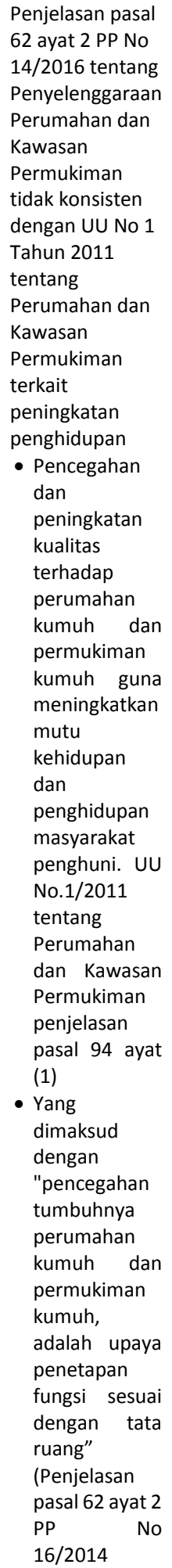 & $\begin{array}{l}\text { Diatur PP No } \\
64 / 2016 \text { tentang } \\
\text { Pembangunan } \\
\text { Perumahan MBR } \\
\text { konsisten dengan } \\
\text { UU No } 1 / 2011 \\
\text { tentang } \\
\text { Perumahan dan } \\
\text { Kawasan } \\
\text { Permukiman }\end{array}$ & $\begin{array}{l}\text { PP No } 14 / 2016 \text { tentang } \\
\text { Penyelenggaraan Perumahan } \\
\text { dan Kawasan Permukiman } \\
\text { pasal } 103 \text { konsisten dengan UU } \\
\text { No } 1 / 2011 \text { pasal } 131 \\
\text { - pelibatan masyarakat dalam } \\
\text { perencanaan, pembangunan, } \\
\text { pemanfaatan dan } \\
\text { pengendalian; informasi } \\
\text { - pemberian kawasan } \\
\text { rencana derbuka } \\
\text { permukiman secara tera } \\
\text { kepada masyarakat; } \\
\text { - pemberian hak ganti rugi } \\
\text { bagi setiap orang yang } \\
\text { terkena dampak } \\
\text { Penyelenggaraan } \\
\text { perumahan dan Kawasan } \\
\text { Permukiman; dan/atau } \\
\text { - pemberian insentif kepada } \\
\text { setiap orang yang dengan } \\
\text { sukarela memberikan } \\
\text { haknya untuk dimanfatkan } \\
\text { bagi kepentingan umum }\end{array}$ \\
\hline
\end{tabular}




\begin{tabular}{|c|c|c|c|c|c|}
\hline $\begin{array}{l}\text { Level } \\
\text { Kebijakan/ } \\
\text { Perundang- } \\
\text { undangan }\end{array}$ & $\begin{array}{l}\text { Jaminan } \\
\text { kepastian } \\
\text { bermukim }\end{array}$ & $\begin{array}{l}\text { Penyediaan } \\
\text { layanan dasar dan } \\
\text { pengembangan } \\
\text { permukiman in situ }\end{array}$ & $\begin{array}{l}\text { Peningkatan } \\
\text { produktifitas } \\
\text { masyarakat } \\
\text { miskin }\end{array}$ & $\begin{array}{c}\text { Akses ke } \\
\text { perumahan murah }\end{array}$ & $\begin{array}{l}\text { Partisipasi masyarakat dalam } \\
\text { pengambilan keputusan }\end{array}$ \\
\hline $\begin{array}{l}\text { Peraturan } \\
\text { Menteri }\end{array}$ & $\begin{array}{l}\text { Tidak diatur di } \\
\text { Permen PUPR } \\
\text { No 2/2016 } \\
\text { tentang } \\
\text { Peningkatan } \\
\text { Kualitas } \\
\text { Terhadap } \\
\text { Perumahan } \\
\text { Kumuh dan } \\
\text { Permukiman } \\
\text { Kumuh, } \\
\text { diserahkan } \\
\text { pengaturannya } \\
\text { pada Perda } \\
\text { dengan } \\
\text { mengikuti } \\
\text { peraturan yang } \\
\text { berlaku }\end{array}$ & $\begin{array}{l}\text { Diatur dalam } \\
\text { Permen PUPR No } \\
\text { 2/2016 tentang } \\
\text { Peningkatan } \\
\text { Kualitas Terhadap } \\
\text { Perumahan Kumuh } \\
\text { dan Permukiman } \\
\text { Kumuh } \\
\text { - Pola penanganan } \\
\text { permukiman } \\
\text { kumuh terdiri } \\
\text { atas pemugaran, } \\
\text { peremajaan dan } \\
\text { permukiman } \\
\text { kembali, dengan } \\
\text { definisi sama } \\
\text { dengan UU No } \\
\text { 1/2011 tentang } \\
\text { Perumahan dan } \\
\text { Kawasan } \\
\text { Permukiman } \\
\text { dan PP No } \\
\text { 14/2016 tentang } \\
\text { tentang } \\
\text { Penyelenggaraan } \\
\text { Perumahan dan } \\
\text { Kawasan } \\
\text { Permukiman } \\
\text { Menambahkan } \\
\text { detail pendikator } \\
\text { pengukuran } \\
\text { tingkat } \\
\text { kekumuhan pada } \\
7 \\
\text { kekumuhan yang } \\
\text { disebutkan } \\
\text { dalam pasal } 108 \\
\text { PP No 14/2016 } \\
\text { Pentang tentang } \\
\text { Penggaraan } \\
\text { Penan dan }\end{array}$ & Tidak diatur & $\begin{array}{l}\text { Permendagri No } \\
\text { 55/2017 tentang } \\
\text { Pelaksanaan } \\
\text { Perizinan dan } \\
\text { Nonperizinan } \\
\text { Pembangunan } \\
\text { Perumahan Bagi } \\
\text { Masyarakat } \\
\text { Berpenghasilan } \\
\text { Rendah Di Daerah, } \\
\text { konsisten dengan } \\
\text { UU No 1/2011 } \\
\text { tentang } \\
\text { Perumahan dan } \\
\text { Kawasan } \\
\text { Permukiman dan } \\
\text { PP No 64/2016 } \\
\text { tentang } \\
\text { Pembangunan } \\
\text { Perumahan MBR }\end{array}$ & $\begin{array}{l}\text { Permen PUPR No 2/2016 } \\
\text { tentang Peningkatan Kualitas } \\
\text { Terhadap Perumahan Kumuh } \\
\text { dan Permukiman Kumuh Pasal } \\
\text { 44-50 konsisten dengan UU No } \\
\text { 1/2011tentang Perumahan } \\
\text { dan Kawasan Permukiman } \\
\text { pasal } 131 \text { dan PP No 14/2016 } \\
\text { tentang Penyelenggaraan } \\
\text { Perumahan dan Kawasan } \\
\text { Permukiman pasal } 103 \\
\text { - pelibatan masyarakat dalam } \\
\text { penetapan lokasi, } \\
\text { perencanaan pembangunan, } \\
\text { pemanfaatan dan } \\
\text { pengelolaan } \\
\text { - Pelibatan masyarakat dalam } \\
\text { pelaskanaan dilakukan } \\
\text { dengan pembentukan KSM }\end{array}$ \\
\hline
\end{tabular}

Sumber: Olahan Peneliti

\section{Kebijakan dan Program Penanganan Permukiman Kumuh di Tingkat Daerah}

Kebijakan dan program penanganan permukiman kumuh di tingkat daerah meliputi kebijakan dan program Pemerintah Provinsi Nusa Tenggara Barat dan kebijakan/ program Pemerintah Kota Mataram. Beberapa temuan dalam pelaksanaan penanganan permukiman kumuh di tingkat kolektif adalah sebagai berikut:

a. Pemerintah Provinsi NTB sejak tahun 2016 lebih banyak menitikberatkan program kegiatannya kepada penanganan perumahan kumuh. Tingginya backlog perumahan dan ditambah lagi dengan bencana gempa bumi yang terjadi pada tahun 2018 menyebabkan prioritas ini tetap tidak beralih sampai dengan rencana penanganan perumahan dan permukiman kumuh tahun 2023.

b. Perda Provinsi tentang penanganan kawasan permukiman dan dokumen strategi penanganan permukiman kumuh belum disusun di tingkat Provinsi NTB. Fungsi Pemerintah Provinsi untuk sinkronisasi penanganan permukiman kumuh di wilayahnya menjadi tidak optimal. 
Namun untuk dukungan implementasi, Pemerintah Provinsi NTB telah membantu penanganan permukiman kumuh di Kota Mataram dengan cara memfasilitasi pendanaan dari pusat terhadap kegiatan-kegiatan penanganan permukiman kumuh prioritas di Kota Mataram. Salah satu kegiatan Pemerintah Provinsi NTB yang berkaitan langsung dengan penanganan permukiman kumuh, yaitu Gerakan Zero Waste dirasakan efektif dalam mendukung penanganan permukiman kumuh di Kota Mataram.

c. Pemerintah Kota Mataram telah mengeluarkan Perda tentang Penyelenggaraan Pencegahan dan Peningkatan Kualitas Perumahan Kumuh dan Permukiman Kumuh, dan juga dokumen RP2KPKP $^{2}$ sebagai bentuk rencana implementasi penanganan permukiman kumuh di Kota Mataram. Dari segi penanganan permukiman kumuh yang holistik, akses terhadap perumahan murah merupakan aspek yang belum diatur dalam Perda dan dokumen tersebut.

d. Terkait beberapa peraturan perundangan di tingkat konstitusional yang belum detail diatur atau tidak koheren satu sama lain, tidak harus membatasi Pemerintah Provinsi/Kota untuk mengambil keputusan di tingkat pilihan kolektif. Meskipun, hal ini mungkin membutuhkan usaha dan koordinasi ekstra untuk mewujudkannya. Sebagai contoh, kepastian bermukim di bantaran Sungai Jangkok dapat diselesaikan setelah Pemerintah Kota Mataram berkoordinasi intensif dengan pihak BBWS (Balai Besar Wilayah Sungai, sebagai organ Kementerian PUPR di Daerah) terkait batas wilayah sungai. Pemerintah Kota Mataram dapat menentukan fungsi permukiman di luar batas kewenangan BBWS, dan hal tersebut ditetapkan dalam Perda tentang Penyelenggaraan Pencegahan dan Peningkatan Kualitas Perumahan Kumuh dan Permukiman Kumuh.

e. Implementasi Penanganan Permukiman Kumuh di Kota Mataram tidak dapat ditangani sendiri oleh Pemerintah Kota Mataram. Dukungan pendanaan dari luar Pemerintah Kota, seperti dari BAZNAS Kota Mataram, APBD Provinsi NTB dan juga dana aspirasi DPRD Kota Mataram, sangat diperlukan.

\section{Pelaksanaan Program Penanganan Permukiman Kumuh di Tingkat Komunitas}

Di tingkat operasional ditinjau bagaimana program dan kegiatan yang dilaksanakan dalam penanganan permukiman kumuh di Kelurahan Bintaro dan Kelurahan Banjar Kota Mataram. Beberapa temuan pada implementasi penanganan permukiman kumuh di Kelurahan Bintaro dan Kelurahan Banjar adalah sebagai berikut:

\section{Tabel 5. Temuan Pelaksanaan Penanganan Permukiman Kumuh Di Kel Bintaro dan} Kel. Banjar, Kota Mataram

\begin{tabular}{|c|c|c|c|}
\hline No & $\begin{array}{c}\text { Penanganan } \\
\text { Permukiman Kumuh }\end{array}$ & Kelurahan Bintaro & Kelurahan Banjar \\
\hline 1 & $\begin{array}{l}\text { Aspek Kepastian } \\
\text { Bermukim }\end{array}$ & $\begin{array}{l}\text { - Warga permukiman kumuh banyak } \\
\text { didominasi oleh pendatang yang menempati } \\
\text { lahan sempadan pantai sehingga Pemerintah } \\
\text { Kota Mataram merencanakan relokasi } \\
\text { permukiman namun ditolak oleh masyarakat } \\
\text { karena merasa lokasi yang disiapkan jauh } \\
\text { dari sumber penghidupan mereka. } \\
\text { - Pengusiran warga oleh pemilik lahan di } \\
\text { sempadan pantai menimbulkan gejolak di } \\
\text { masyarakat. Hal ini menyebabkan } \\
\text { Pemerintah Kota Mataram mengubah } \\
\text { rencana penanganan menjadi pembangunan } \\
\text { rusunawa dan penyiapan hunian sementara }\end{array}$ & $\begin{array}{l}\text { - Warga masyarakat } \\
\text { Kelurahan Banjar lebih } \\
\text { aman dalam hal kepastian } \\
\text { bermukim karena mereka } \\
\text { memang tinggal di lokasi } \\
\text { tersebut sejak puluhan tahun, } \\
\text { sehingga pendaftaran hak } \\
\text { milik tanah secara sporadik } \\
\text { tidak menemui kendala. } \\
\text { - Keberhasilan Pemerintah } \\
\text { Kota Mataram bernegosiasi } \\
\text { dengan Pihak BBWS dalam } \\
\text { hal batas wilayah sungai, }\end{array}$ \\
\hline
\end{tabular}

\footnotetext{
${ }^{2}$ RP2KPKP adalah dokumen Rencana Pencegahan dan Penanganan Kawasan Permukiman Kumuh di Perkotaan
} 


\begin{tabular}{|c|c|c|c|}
\hline No & $\begin{array}{c}\text { Penanganan } \\
\text { Permukiman Kumuh }\end{array}$ & Kelurahan Bintaro & Kelurahan Banjar \\
\hline & & $\begin{array}{l}\text { bagi masyarakat yang sudah tidak memiliki } \\
\text { tempat tinggal atau masih menempati } \\
\text { sempadan pantai yang berbahaya. }\end{array}$ & $\begin{array}{l}\text { memberikan kepastian } \\
\text { tentang sempadan sungai } \\
\text { yang berfungsi sebagai } \\
\text { permukiman, sehingga dapat } \\
\text { diatur dalam Perda. Hal ini } \\
\text { memberikan kepastian } \\
\text { bermukim. }\end{array}$ \\
\hline 2 & Aspek Keberlanjutan & 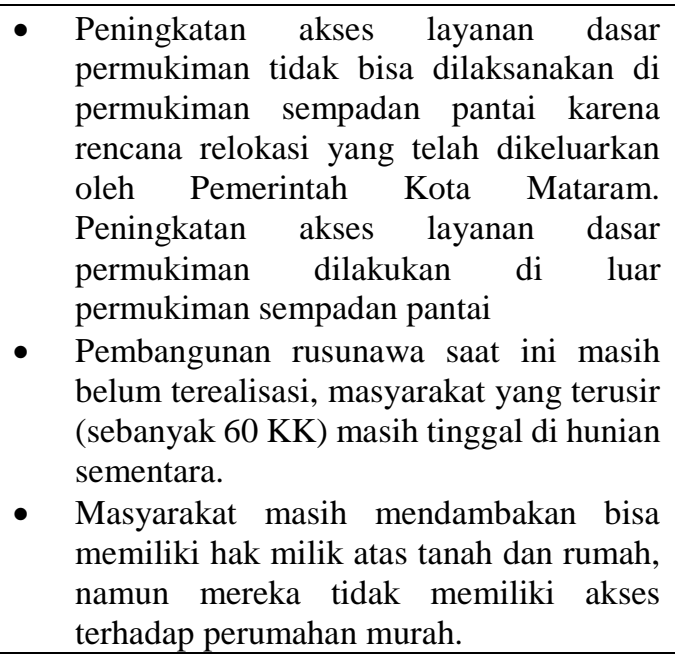 & $\begin{array}{l}\text { - Penanganan permukiman } \\
\text { secara setempat di Kelurahan } \\
\text { Banjar diterima dengan baik } \\
\text { dan berjalan tanpa hambatan } \\
\text { mengingat mereka tidak } \\
\text { perlu meninggalkan tempat } \\
\text { yang telah menjadi sumber } \\
\text { penghidupan mereka } \\
\text { - Penataan sempadan sungai di } \\
\text { Kelurahan Banjar memotong } \\
\text { beberapa bangunan warga, } \\
\text { namun warga merelakan } \\
\text { dengan ganti rugi yang } \\
\text { pantas. }\end{array}$ \\
\hline 3 & $\begin{array}{l}\text { Aspek Pelibatan } \\
\text { Masyarakat }\end{array}$ & $\begin{array}{l}\text { Pelibatan masyarakat di Kelurahan } \\
\text { Bintaro dalam hal sosialisasi, persuasi dan } \\
\text { pengambilan keputusan yang terkesan } \\
\text { tidak optimal menyebabkan penolakan- } \\
\text { penolakan dan gesekan-gesekan yang } \\
\text { menghambat realisasi penanganan } \\
\text { permukiman kumuh. }\end{array}$ & $\begin{array}{l}\text { - Pelibatan masyarakat di } \\
\text { Kelurahan Banjar dalam hal } \\
\text { sosialisasi, persuasi maupun } \\
\text { pengambilan keputusan } \\
\text { tampak lebih aktif sehingga } \\
\text { realisasi dari rencana yang } \\
\text { telah disepakati menjadi } \\
\text { lebih mudah }\end{array}$ \\
\hline
\end{tabular}

Sumber: Olahan peneliti

\section{KESIMPULAN DAN REKOMENDASI Kesimpulan}

Tantangan pelaksanaan penanganan permukiman kumuh di Indonesia adalah pada aspek institutional governance yang belum berjalan dengan baik. Indikasinya dapat dilihat pada kebijakan yang disusun dan dilaksanakan pada constitutional level, yang belum koheren dan belum sepenuhnya diturunkan ke dalam kebijakan yang lebih rinci untuk dapat diimplementasikan dan/atau disinkronkan pada collective level. Karena itu, beberapa kebijakan yang diterjemahkan sendiri pada collective level (terutama oleh Pemerintah Kota) dikhawatirkan akan berbeda semangat maupun arahnya. Namun demikian, kebijakan yang diambil pada collective level terutama oleh Pemerintah Kota juga belum tentu secara konsisten dapat dilaksanakan pada operational level, karena pengambilan keputusan di tingkat komunitas dipengaruhi oleh dinamika di dalam komunitas.

Tantangan yang dihadapi dalam penanganan permukiman kumuh dan penyebabnya dalam sudut pandang institusional dapat digambarkan sebagai berikut : 


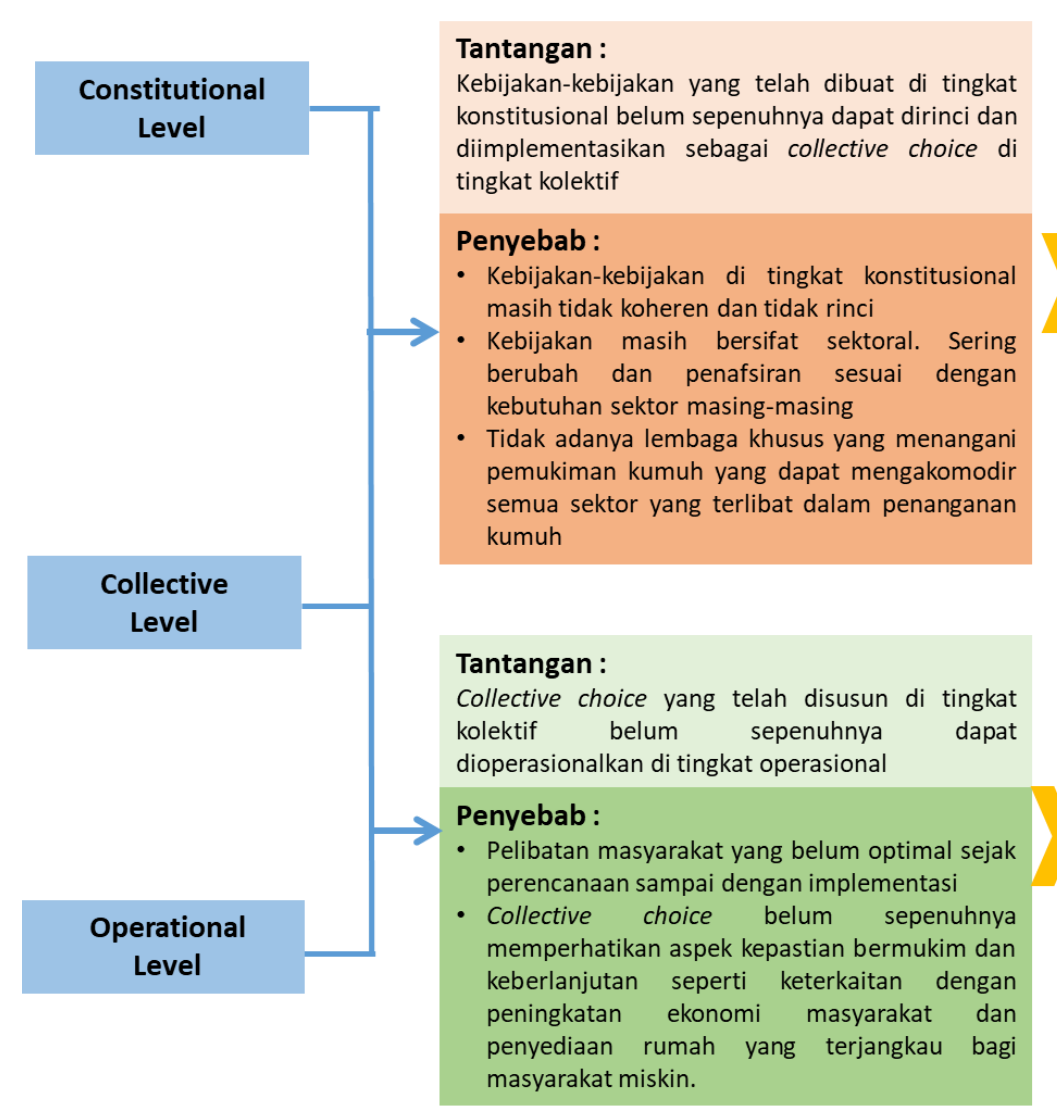

Contoh :

- Pemindahan warga permukiman tepi pantai Kel. Bintaro yang dianggap menempati ruang yang bukan peruntukannya, sedangkan di satu sisi mengizinkan penataan permukiman secara in situ bagi warga permukiman tepi sungai Kel. Banjar.

- Tidak koherennya antara UU No $1 / 2011$ tentang Perumahan dan Kawasan Permukiman dengan UU No 26/2007 tentang Penataan Ruang serta PP No. 38/2011 tentang Sungai pasal 3 terkait sudut pandang dalam melihat permukiman sebagai suatu fungsi.

Gambar 2. Diagram The Three Worlds of Actions, Tantangan dalam Penanganan Kumuh di Kota Mataram

\section{Rekomendasi}

Berdasarkan kesimpulan di atas, maka untuk perbaikan penanganan permukiman kumuh di masa depan direkomendasikan hal-hal sebagai berikut:

a. Perlu dilakukan sinkronisasi antara berbagai level peraaturan-perundang-undangan, agar tidak menimbulkan penafsiran yang berbeda pada collective level. Di samping itu diperlukan juga peraturan yang lebih rinci agar ketidakkoherenan antar-perundangan dapat dijembatani.

b. Peran dan wewenang Provinsi dalam penanganan permukiman kumuh perlu lebih dioptimalkan untuk mensinkronisasi antara kepentingan Pusat dan Daerah. Di samping itu juga sebagai jembatan koordinasi untuk kebutuhan administratif yang terkadang cukup lama bila dilakukan oleh kota/kabupaten ke tingkat pusat.

c. Kepastian bermukim adalah hak dasar warga negara dan menjadi tanggung jawab negara, sehingga bukan hanya peraturan terkait kepastian bermukim yang perlu disinkronkan, namun juga harus diatur secara rinci dalam peraturan yang lebih implementatif. Dalam pelaksanaan penanganan permukiman kumuh hendaknya penanganan kepastian bermukim ditempatkan pada langkah pertama sebelum pelaksanaan penyediaan infrastruktur permukiman dilakukan. Pengalaman di Kelurahan Banjar dapat menjadi pelajaran.

d. Aspek keberlanjutan dalam penanganan permukiman kumuh bukan hanya sebatas pemenuhan layanan dasar permukiman. Lebih dari itu juga berkaitan dengan peningkatan ekonomi masyarakat dan akses terhadap perumahan murah. Implementasi yang terjadi selama ini sasarannya adalah layanan dasar permukiman, peningkatan ekonomi dan akses ke perumahan murah. Ketiganya memiliki basis data sasaran yang berbeda-beda, sehingga sulit melakukan 
sinkronisasi agar aspek keberlanjutan untuk mencegah timbulnya kumuh kembali. Kasus di Kelurahan Bintaro menunjukkan bahwa perbaikan rumah dan pembangunan rusunawa bukan menjadi solusi akhir, namun diperlukan akses ke perumahan murah untuk mendukung keberlanjutan penanganan permukiman kumuh.

e. Penanganan permukiman kumuh secara in situ yang didukung oleh penjaminan kepastian bermukim berdasarkan pengalaman di Kelurahan Banjar lebih diterima oleh masyarakat, dibandingkan dengan pengalaman di Kelurahan Bintaro yang harus dilakukan relokasi. Penanganan permukiman kumuh secara relokasi hendaknya tidak jauh dari lokasi setempat dan tetap memperhatikan kebutuhan sumber penghidupan warga agar aspek keberlanjutan penanganan permukiman kumuh terpenuhi.

f. Pelibatan masyarakat dalam penanganan permukiman kumuh harus dimulai dengan pemberian informasi dan persuasi yang baik, di samping keterlibatan komunitas didorong, dengan membentuk perwakilan komunitas untuk menyuarakan aspirasinya.

g. Berdasarkan pengalaman dari kasus studi kolektif ini, maka penanganan permukiman kumuh yang efektif harus dilakukan secara holistik yang mencakup: (1) pemberian jaminan kepemilikan kepada keluarga miskin yang tinggal di pemukiman yang tidak sah dan meningkatkan akses mereka ke perumahan murah dan pembiayaan perumahan bersubsidi; (2) peningkatan kondisi kehidupan masyarakat miskin melalui penyediaan layanan dasar dan pengembangan permukiman kumuh secara in situ; (3) peningkatan produktivitas masyarakat miskin perkotaan dengan mengembangkan keterampilan dan menyediakan akses ke kredit mikro; dan (4) pemberdayaan masyarakat miskin perkotaan melalui pengembangan masyarakat dan mendorong partisipasi mereka dalam pengambilan keputusan.

\section{DAFTAR PUSTAKA}

Bah, E., M.. (2018). Housing Market Dynamics in Africa. Palgrave MacMillan, London.

BKM Kel. Banjar. (2015). Dokumen Rencana Penataan Lingkungan Permukiman (RPLP) Kel. Banjar 2015-2019. BKM Kel. Banjar, Mataram

BKM Kel. Bintaro. (2015). Dokumen Rencana Penataan Lingkungan Permukiman (RPLP) Kel. Bintaro, 2015-2019. BKM Kel. Bintaro, Mataram

Cole, D. H. (2013). "The Varieties of Comparative Institutional Analysis". School of Public \& Environmental Affairs Research Paper No. 2012-10-03, Hal:101-127. Bloomington-Indiana: Indiana University.

Fahmi, E. (2020). "Pendekatan Penelitian Kualitatif dalam Kajian Perkotaan dan Wilayah". Manuskrip. Universitas Tarumanagara, Jakarta.

Fahmi, E. et.al. (2003). Analysis of Multistakeholder Forestry Processes In Indonesia, Yogyakarta: INSIST and Partners.

Hasnawi, et.al. (2019). "Improvement of Community Governance to Support Slum Upgrading in Indonesia". The Indonesian Journal of Development Planning Vol. III No. 3. Hal:347-358. Bappenas, Jakarta.

https://rujak.org/hak-atas-kota-hak-untuk-bermukim-di-pusat-kota/

Kacaribu, T. M. (2019). "Kinerja Perum Perumnas dalam Pelaksanaan Penugasan Pembangunan Perumahan bagi MBR Sesuai Amanat PP No. 83 Tahun 2015: Studi tentang Desain Kelembagaan". Tesis tidak dipublikasikan. Jakarta: Universitas Tarumanagara

Kiser, L. L. dan Elinor Ostrom. (1982). "The Three Worlds of Action: A Metatheoretical Synthesis of Institutional Approaches". In Elinor Ostrom (ed). Strategies of Political Inquiry. Sage Publications, Beverly Hills.

Mangira, P., et al. (2020). "Tenure-Infrastructure-Livelihoods (T-I-L) Nexus in Slum Upgrading: An Emerging Paradigm”. Africa Habitat Review Journal Volume 14 Issue 3. Nairobi, 
Kenya.

Ostrom, E. (1992). Crafting Institutions for Self-Governing Irrigation Systems. ICS Press, San Francisco

Oswar, M. (2013). Perumahan Swadaya. Konsep, Pembelajaran dan Praktek Unggulan. Bappenas, Jakarta

Ostrom, V, CM Tiebout, dan R. Warren. (1961). "The Organization of Government in Metropolitan Areas: A Theoretical Inquiry". American Political Science Review 55:831-42

Pokja PKP Kota Mataram. (2017). Paparan Memorandum Program RP2KPKP Kota Mataram Bappeda Kota Mataram.

Rahman, HM Tuihedur, et al. (2017). "A Framework For Analyzing Institutional Gaps In Natural Resource Governance”. International Journal of the Commons Vol. 11, No 2, hal: 823-853.

Sibyan, I. A. (2020). "Rethinking Slum Planning: A Comparative Study of Slum Upgrading Projects". Journal of Regional and City Planning vol. 31, no. 1, hal. 1-11. ITB Institute for Research and Community Services, Bandung.

Werlin, H. (1999). '’The Slum Upgrading Myth". Urban Studies, 36(9): 1523-1534 